This Indiana State Summary educates policymakers and the public

about EERE investments and their positive impacts in Indiana.
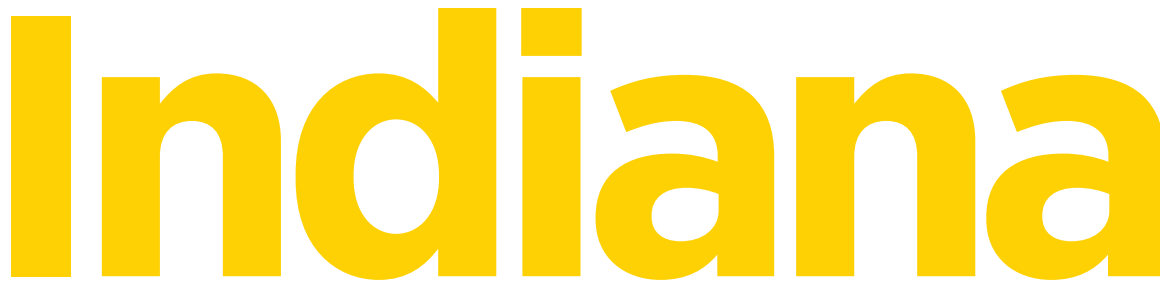

The U.S. Department of Energy (DOE) is pursuing an all-ofthe-above approach to developing every source of American energy. The Office of Energy Efficiency and Renewable Energy (EERE) leads DOE efforts to build a strong clean energy economy, a strategy that is aimed at reducing our reliance on foreign oil, saving families and businesses money, creating middle-class jobs, and reducing pollution.

This strategy will position the United States as the global leader in clean energy, increasing our nation's economic competitiveness. In 2012, \$268 billion was invested globally in clean energy, a $500 \%$ increase since $2004 .{ }^{1}$ Trillions of dollars will be invested in the coming decades. Clean energy represents one of the most important economic development races of the 21st century. We face a stark choice - the clean energy technologies of tomorrow can be invented and manufactured in Indiana and the rest of the United States for domestic use and export around the world, or we can cede global leadership and import those technologies from China, India, Germany, and elsewhere.

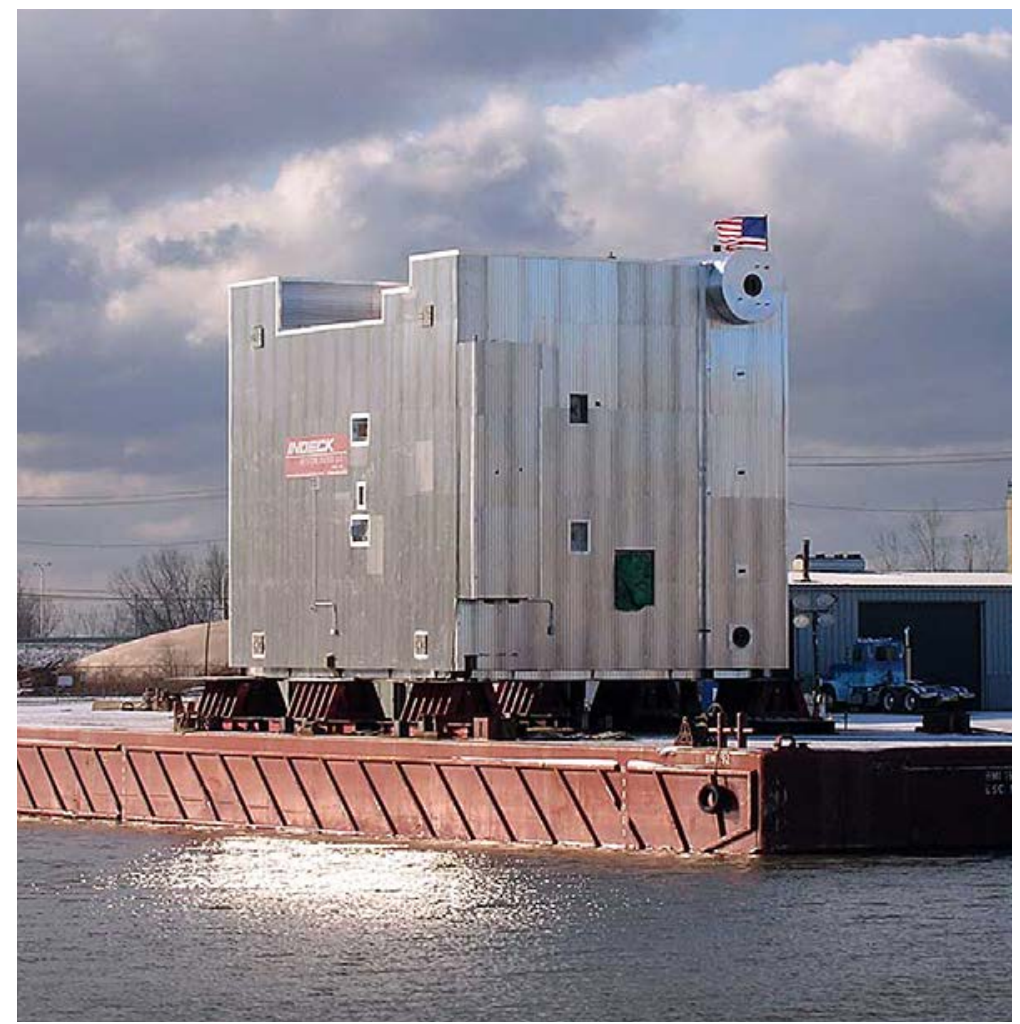

ArcelorMittal USA, Inc. installed an energy-efficient boiler at its Indiana Harbor Steel Mill that has the capacity to reduce carbon dioxide emissions by 330,000 tons annually. Photo from ArcelorMittal

\section{Indiana's Clean Energy Resources and Economy}

- Clean Economy Jobs (2010): 53,600+

- Average Annual Growth Rate of Clean Economy Jobs (2003-2010): 1.5\%

- Average Annual Wage of Clean Economy Jobs $(\$ 2009): \$ 37,162^{2}$

Strong in clean energy manufacturing, renewables, and efficiency technologies, Indiana ranks in the top third of states in wind energy potential, with a capacity of more than 148,227 megawatts-enough to generate more than four times the state's current electricity consumption. ${ }^{3}$ The four utility-scale wind power plants currently operating in Indiana generate more than 1,000 megawatts-up from virtually zero in $2005 .{ }^{4}$ Several dozen Indiana companies produce components, tools, or materials for the wind energy industry.

Indiana's automotive manufacturing industry employed more than 84,000 people and produced more than $\$ 8$ billion worth of goods in 2010. ${ }^{5}$ Several of Indiana's auto and auto part manufacturers have entered or are preparing to enter the growing clean transportation sector.

Indiana is one of $\mathbf{2 0}$ states with a binding energy savings target. The annual savings target starts at $0.3 \%$ in 2010 and will ramp up to $2 \%$ in $2019 .{ }^{6}$ By 2019 , this effort is expected to save more than 2.3 million megawatt hours $-\$ 177$ million worth of electricity-per year statewide. ${ }^{7}$ Indiana utility companies also sponsor 43 rebate programs for energy efficiency and renewable energy, as well as a loan program for residential energy efficiency improvements. ${ }^{8}$

\section{USNERG}

Energy Efficiency \& Renewable Energy 


\section{EERE and Indiana}

EERE helps create Indiana's clean energy economy today, developing and delivering innovative, market-driven solutions for the following:

- Sustainable transportation - making transportation cleaner and more efficient through solutions that put electric drive vehicles on the road and replace oil with clean domestic fuels

- Renewable electricity generation - reducing the cost of renewable energy through solutions that squeeze more usable power from sustainable resources and improve the economics of manufacturing and installation

\section{- Energy-saving homes, buildings, and manufacturing -} developing cost-effective energy-saving solutions that help make our country run better through increased efficiency_promoting better plants, manufacturing processes, and products; more efficient new homes and improved older homes; and other solutions to enhance the buildings in which we work, shop, and lead our everyday lives.

\section{EERE |nvestments in Indilana}

EERE invests in Indiana through a broad range of clean energy projects, including vehicles, geothermal, solar, wind, and other technologies. Through the research, demonstration, and deployment activities we conduct with Indiana and its businesses, universities, nonprofits, and local governments, EERE supports cities, communities, and families to develop innovative, cost-effective clean energy solutions.

\section{Sustainable Transportation}

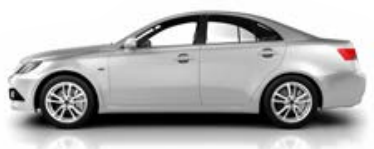

Largest U.S. Hybrid Electric Vehicle Supplier Expands Manufacturing Facility to Create Jobs and Invigorate Local Community

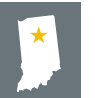

Kokomo, Indiana

EERE investment: $\$ 96.7 \mathrm{M}$

Delphi, the largest North American supplier for hybrid electric vehicle power electronics components and energy management systems, is expanding its Kokomo manufacturing facility with an EERE investment of $\$ 89.3$ million. Delphi has already created more than 198 direct jobs, and expects the expansion to create more than 900 direct and indirect jobs. ${ }^{9}$ EERE provided Delphi an additional $\$ 7.4$ million in January 2010, which the company also matched, to develop a novel low-temperature combustion system for light-duty vehicles that could improve fuel economy by at least 25\%. ${ }^{10}$ In addition, in June 2012, Delphi competed and was selected for funds through EERE's Innovative Manufacturing Initiative for the development of lasers to be used in a new production process for fuel injectors. This new process is expected to yield energy savings of up to $25 \%$ relative to current practices. ${ }^{11}$

\section{Hybrid Electric Drive Systems Come to the Commercial Truck Market}

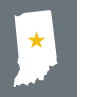

Indianapolis, Indiana

EERE investment: $\$ 62.8 \mathrm{M}$

EERE's investment in Allison Transmission, combined with the company's matching $\$ 62.8$ million investment, will fund the retooling of a facility in Indianapolis for subassembly and testing of its H3000 hybrid drive systems for the commercial truck market. Allison estimates that this electric drive technology can improve fuel economy by $25 \%-35 \%$ compared to conventional trucks with internal combustion engines. Since the end of November 2012, Allison has had the capacity in place to annually produce $20,000 \mathrm{H} 3000$ hybrid drive systems for medium- and heavy-duty sized trucks and buses. ${ }^{12}$

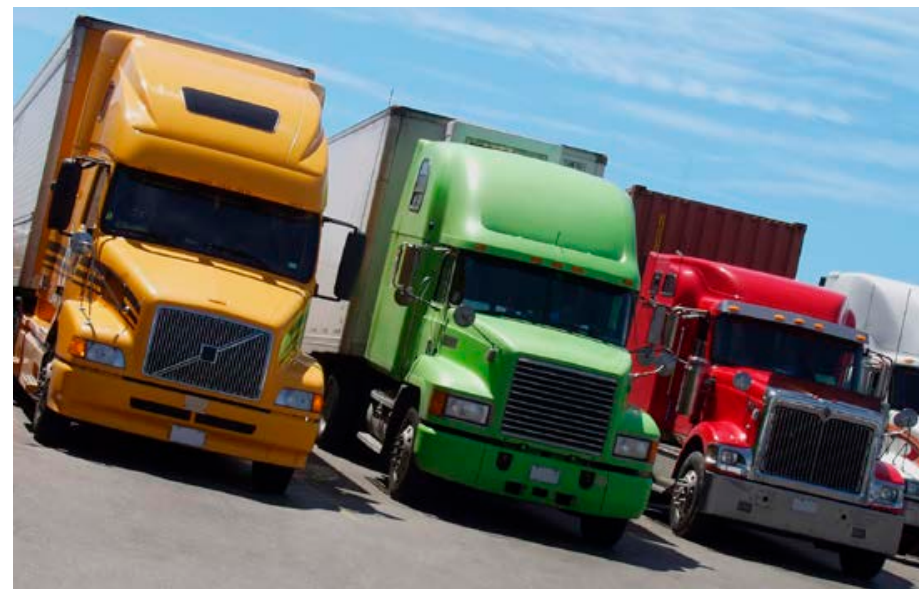

Allison Transmission, with EERE's support, is developing electric drive technology which is estimated to improve fuel economy by 25\%-35\% for commercial trucks. Photo from istock 2312011 
Leading Automotive Parts Manufacturer Develops Lower-Cost, Higher Performance Hybrid Electric Motors and Controls

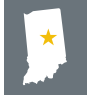

Pendleton, Indiana

EERE investment: $\$ 60.2 \mathrm{M}$

Remy International is a leading global manufacturer and remanufacturer of automotive parts, including starters, alternators, and hybrid motors. EERE is partnering with Remy to develop a standardized platform for lower-cost, higher-performance hybrid electric motors and controls, as well as to retool and expand its U.S.-based manufacturing facilities. By creating a family of standardized electric drive motors and scaling their production, the company hopes it will be able to reduce the costs of its products for existing customers in the automotive and heavy-duty vehicle markets. The first phase of the project, which refurbished an existing facility in Pendleton, is complete and has supported 210 direct jobs. Remy is also investing $\$ 60.2$ million in the project. ${ }^{13}$

\section{EERE's SuperTruck Initiative - Improving the Tractor-Trailers that Bring Goods to Our Communities}

The SuperTruck Initiative is an ongoing collaborative effort between EERE and private industry that seeks to revolutionize on-highway commercial transportation by improving the freight hauling efficiency of long-haul Class 8 tractor-trailers by more than $50 \%$. All of the major truck and diesel engine manufacturers in the United States are participating in this effort.

- Developing and Demonstrating Technologies that Improve Engine Efficiency

Fort Wayne, Indiana

EERE investment: $\$ 31 \mathrm{M}$

Navistar, working in cooperation with DOE's Lawrence Livermore National Laboratory and Argonne National Laboratory, is developing and demonstrating technologies to improve truck and trailer aerodynamics, combustion efficiency, waste heat recovery, hybridization, idle reduction, and reduced rolling resistance tires. Navistar, conducting a majority of the work in Fort Wayne, is investing an additional $\$ 52$ million in the project. ${ }^{14}$

\section{- Improving Engine Performance}

Columbus, Indiana

EERE investment: $\$ 53.8 \mathrm{M}$

Cummins, the world's largest diesel engine manufacturer, received funds from EERE for work on in two areas: advanced engine technology and light-duty vehicles. Cummins' work on Class 8 heavy-duty trucks includes the development and demonstration of a highly efficient and clean diesel engine, an advanced waste heat recovery system, an aerodynamic Peterbilt tractor and trailer combination, and a fuel cell auxiliary power unit to reduce engine idling. ${ }^{15}$ Cummins' work on light-duty vehicles are to develop a fuel-efficient, low-emissions diesel engine that is $40 \%$ more fuel efficient than conventional gasoline technology, while meeting 2010 EPA emissions standards. Cummins contributed $\$ 55.3$ million to these projects. These funds will be used to develop a fuel-efficient, low-emissions diesel engine that is $40 \%$ more fuel efficient than conventional gasoline technology, while meeting 2010 EPA emissions standards. ${ }^{16}$

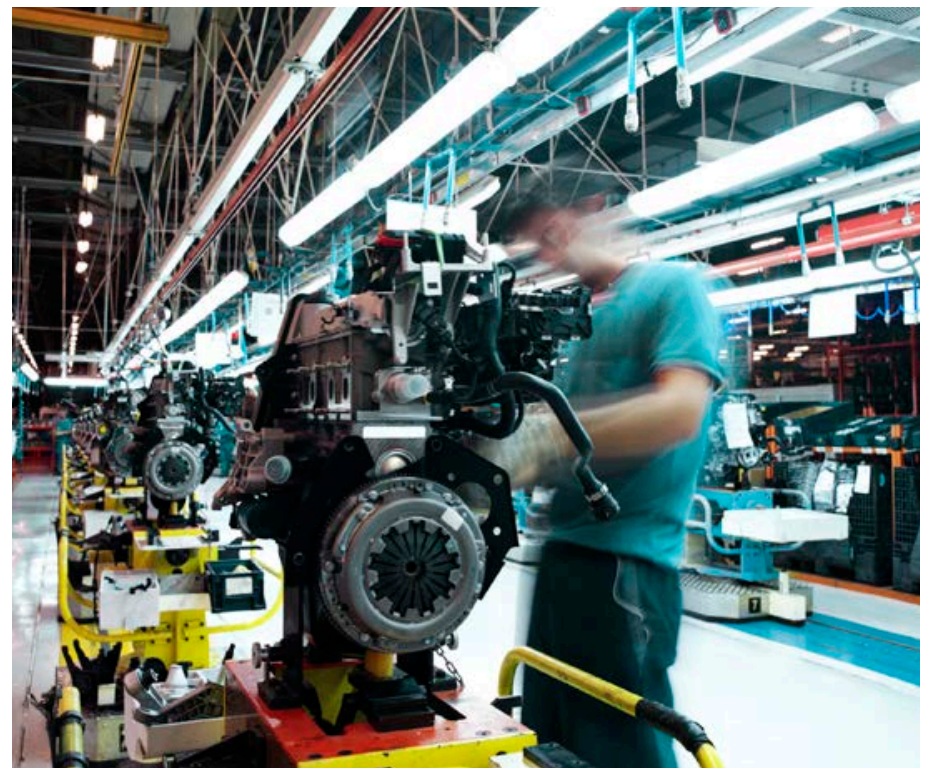

EERE has supported Indiana's auto and auto part manufacturers as they enter or prepare to enter the growing clean transportation sector. Photo from istock 10427481 


\section{Adopting Smart Transportation Solutions}

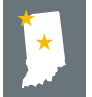

Mooresville and Crown Point, Indiana

EERE investment: $\$ 30 \mathrm{~K}$ anually to each coalition

EERE coordinates a network of nearly 100 Clean Cities coalitions - self-organized groups of local community, government, and business stakeholders whose efforts to adopt smart transportation solutions have displaced more than 4.5 billion gallons of gasoline and diesel since 1993. Indiana is home to two Clean Cities coalitions: Greater Indiana Clean Cities and South Shore Clean Cities. In 2011, these two coalitions reduced fuel consumption by the equivalent of nearly 18 million U.S. gallons of gasoline and prevented more than 130,000 tons of greenhouse gas emissions. Together, the coalitions include more than 350 businesses, local governments, and other organizations, and work to promote the use of the more than 500 alternative fuel and charging stations in Indiana. In 2011, the two coalitions leveraged DOE's support to raise more than $\$ 14$ million from businesses, local governments, other organizations, and non-DOE grants.

\section{Renewable Electricity Generation}

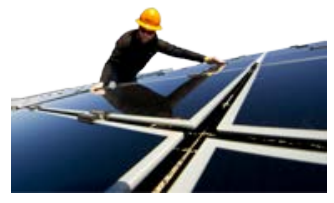

\section{Ball State University Completes Largest U.S. Ground-Source Geothermal System, Saving Millions in Operating Costs}

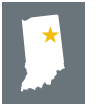

\section{Muncie, Indiana \\ EERE investment: \$5M}

EERE has partnered with Ball State University in Muncie to install a campus-wide ground-source geothermal heating and cooling system - currently the nation's largest. The university anticipates that this system will help save \$2 million annually in operating costs and cut the university's carbon footprint in half. Ball State's geothermal system will replace four aging coal-fired boilers to provide renewable power that will heat and cool 47 university buildings, comprising 5.5 million square feet on the 660-acre campus. The first half of the project was completed in March 2012, with the final half scheduled for completion in 2014. Nearly every component of the system was manufactured in the United States, and Ball State contracted with more than 50 Indiana firms to complete the project. ${ }^{17}$

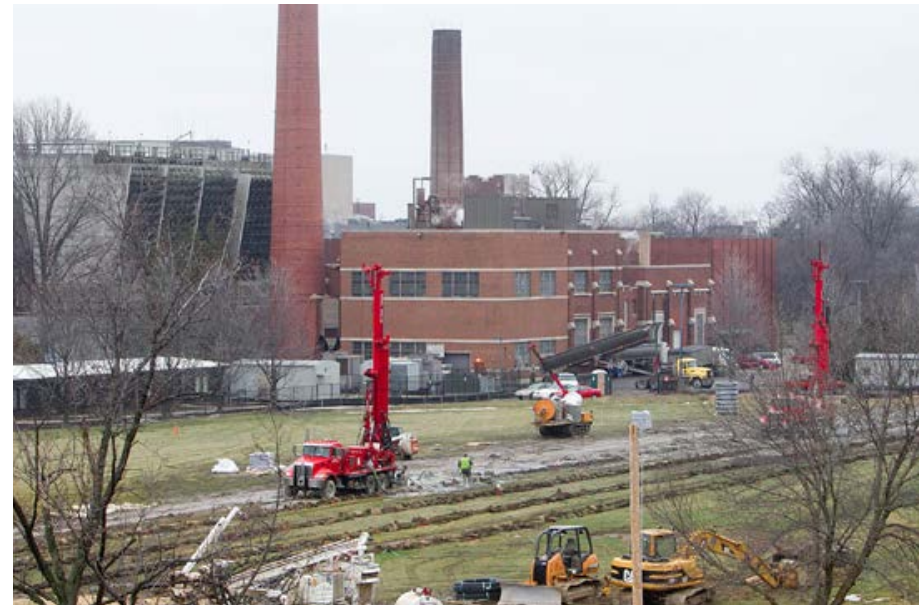

EERE sponsored Ball State University's campus-wide geothermal system, which is expected to save $\$ 2$ million annually in operating costs and cut the university's carbon footprint in half. Here, geothermal boreholes are dug to install the system next to an existing coal-fired power plant. Photo from Ball State

\section{Educating Workers, Consumers, and Students about Wind Power}

Statewide

EERE's Wind Powering America (WPA) is a nationwide initiative designed to educate, engage, and enable critical stakeholders to make informed decisions about how wind energy contributes to the U.S. electricity supply. In Indiana, WPA has education and workforce training programs at Purdue University-Calumet in Hammond and at Ivy Tech Community College in Lafayette. WPA conducted various wind resource analysis exercises, developed a small wind consumer's guide for the state, and supports school wind projects at high schools, colleges, and universities in Akron, Albion, Francesville, Union City, and Upland.

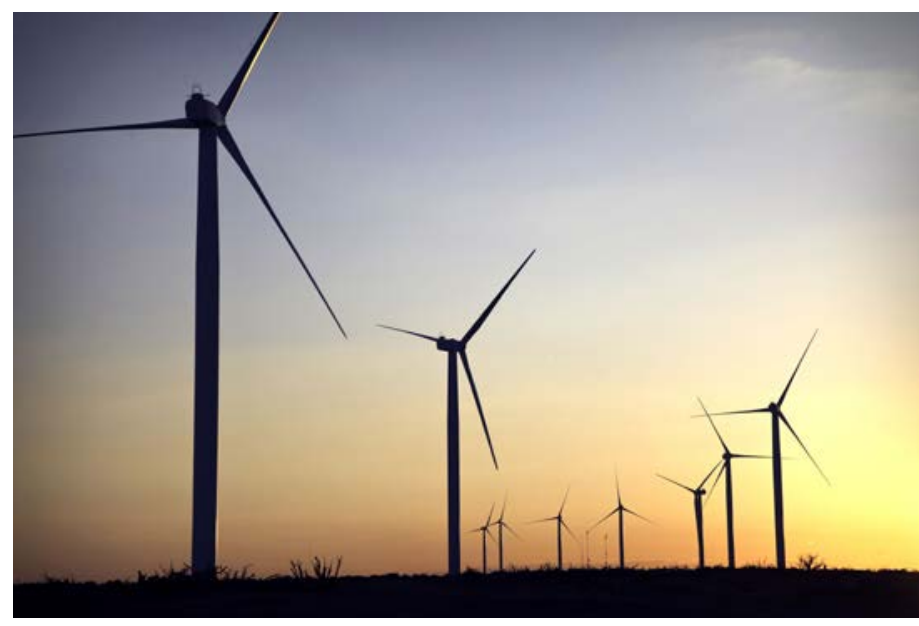

Indiana has the wind energy potential of over 40,000 megawatts, which is more than four times the state's current electricity consumption. Photo from Iberdrola Renewables, Inc., NREL 16706 


\section{Energy-Saving Homes, Buildings, and Manufacturing}

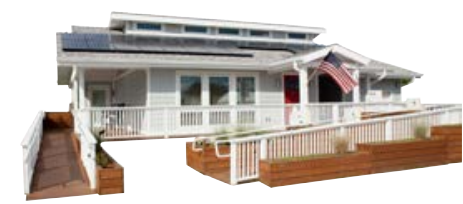

\section{Steel Mill Powered by Waste Heat Recovery System Improves Competitiveness}

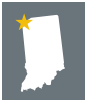

East Chicago, Indiana

EERE investment: $\$ 31.6 \mathrm{M}$

EERE worked with ArcelorMittal USA, Inc. to install an efficient recovery boiler to use waste heat generated during iron-making operations to produce electricity and steam onsite at the company's Indiana Harbor Steel Mill in East Chicago, Indiana. The steam is being used to drive existing turbogenerators onsite, creating enough electricity to power the equivalent of 30,000 households each year and reducing carbon dioxide emissions by 330,000 tons annually, which is equivalent to removing approximately 60,800 cars from the road. The project is estimated to have created 360 jobs related to the design and manufacture of the equipment alone; employ 200 local construction workers; and, by reducing energy costs, help support 5,900 jobs associated with the mill. ${ }^{18}$

\section{Deploying Clean Energy Solutions in Indiana Communities}

EERE invests in the deployment of energy efficiency and renewable energy projects in communities across the Hoosier State, catalyzing economic development, creating jobs, generating clean energy, and reducing utility bills. Of the more than \$249 million in American Recovery and Reinvestment Act (ARRA) funds allotted to the State of Indiana from EERE specifically for deployment projects, more than 99\% has been spent as of March 2013 through the Energy Efficiency and Conservation Block Grant Program, State Energy Program, and Weatherization Assistance Program.

\section{Building Clean Energy Infrastructure}

With financial and technical support from EERE, energy officials at the state level and in 34 communities have selected and overseen the completion of hundreds of projects that are delivering the benefits of clean energy to citizens throughout Indiana. EERE allocated \$116 million in ARRA funds to support activities that

- Increased energy efficiency and cost savings of nearly 1,000 buildings (more than 20 million square feet) through building retrofits
- Installed approximately 20 renewable energy systems, with a total capacity of more than 500 kilowatts of solar energy systems

- Funded nearly 130 workshops, teaching nearly 5,000 people to perform energy audits and install renewable energy systems

- Installed more than 6,000 energy-efficient streetlights and more than 3,000 energy-efficient traffic signals. ${ }^{19}$

\section{Weatherizing Homes for Lower Income Families}

Indiana has spent more than $99 \%$ of the more than $\$ 133$ million in ARRA funds it received to weatherize approximately 23,000 homes, exceeding its goal. This resulted in annual energy savings of approximately 700 billion British thermal units and prevented more than 60,000 metric tons of carbon pollution, the equivalent of taking more than 12,000 passenger vehicles off the road for a year. ${ }^{20}$ The projects have enabled income-eligible families to save hundreds of dollars per year on heating and cooling bills by improving their homes' energy efficiency as well as the health and safety of home environments. ${ }^{21}$

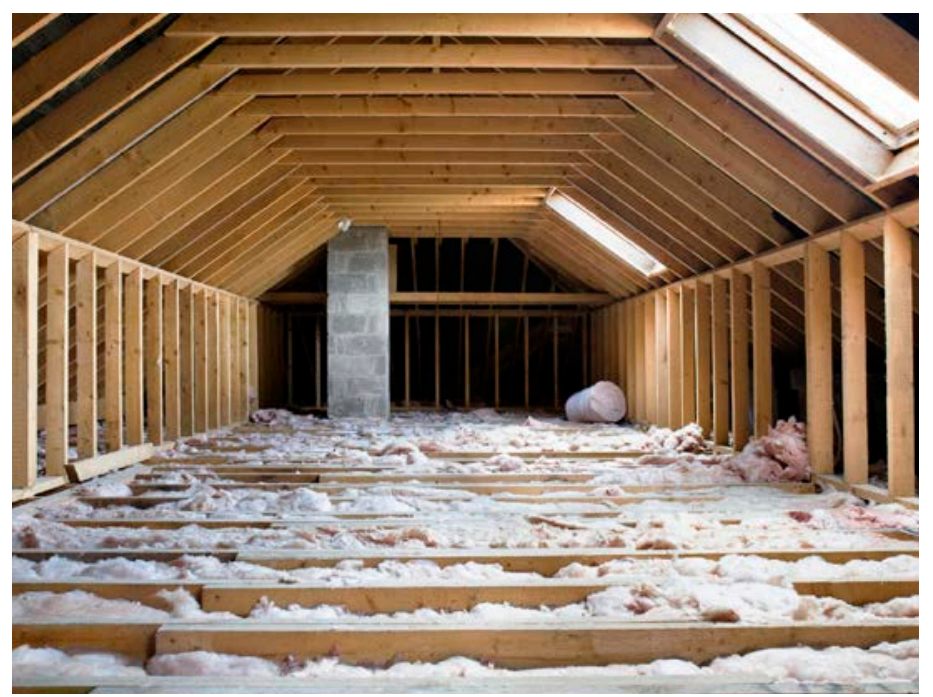

ARRA funds have enabled the state of Indiana to weatherize approximately 25,000 homes. Photo from istock 5392656 


\section{Deployment Project Examples in Indiana Communities}

\section{City of Carmel Replaces Street Lights and Deploys Community Wind Turbines}

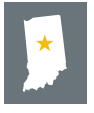

Carmel, Indiana

EERE investment: $\$ 633 \mathrm{~K}$

The City of Carmel replaced half of its existing street lights with light-emitting diodes and deploy small wind turbines to power the city's sewer treatment plant. In addition to creating 30 jobs and saving energy, the project is leveraging hundreds of thousands of dollars from state and local sources.

\section{Purdue Develops the U.S. Renewable Energy Workforce}

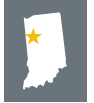

West Lafayette, Indiana

EERE investment: $\$ 500 \mathrm{~K}$

Purdue University has established a comprehensive wind energy program with educational and research components. Funding has helped Purdue develop graduate and undergraduate curricula for energy engineering, focusing on wind energy and including a wind energy certificate program. This funding will help develop the U.S. renewable energy workforce.

\section{Indianapolis Harnesses the Sun and Wind to Power City Infrastructure}

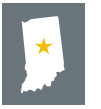

Indianapolis, Indiana

EERE investment: $\$ 250 \mathrm{~K}$

Indianapolis installed a solar photovoltaic system, solar thermal system, and wind-powered outdoor lighting on the City-County Building, a 731,119-square-foot downtown landmark. ${ }^{22}$

\section{Warrick County Saves Energy and Money through Efficiency Measures}

口

Warrick County, Indiana

EERE investment: $\$ 58 \mathrm{~K}$

Warrick County retrofitted its lighting in the Warrick

County Courthouse and the Warrick County Security

Center. The county has already realized more than $\$ 8,000$

in energy savings. ${ }^{23}$

\section{Metal Halide Lighting Puts Out More Light for Less Energy}

回

Shelbyville, Indiana

EERE investment: $\$ 500 \mathrm{~K}$

Ryobi Die Casting USA used this investment, administered through Indiana's Conserving Hoosier Industrial Power program, to replace the high bay fixtures in all three of its manufacturing buildings with Pulse Start Advanced Metal Halide fixtures. These fixtures increased lighting on the shop floor by $300 \%$, while using only $45 \%$ of the initial power input. The Pulse Start fixtures were designed and manufactured in Casey, Illinois.

\section{Logistics Upgrades Heating, Cooling, Lighting, and Control Systems}

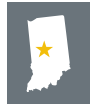

Plainfield, Indiana

EERE investment: $\$ 212 \mathrm{~K}$

MD Logistics used this investment, also administered through Indiana's Conserving Hoosier Industrial Power grant program, to retrofit heating, ventilating, and air conditioning (HVAC); lighting; and control systems at its facility. The company replaced three HVAC units with high efficiency units, retrofitted eight cooling units with ultraviolet $\mathrm{C}$ lighting, and installed direct digital control systems to reduce winter heating costs and summer cooling demand. MD Logistics also had its warehouse lighting upgraded to T5 High Output fluorescent fixtures with motion sensors to turn lights off when an area was unoccupied. 
I“Who's Winning the Clean Energy Race?" Pew Charitable Trusts, April 2012.

http://www.pewtrusts.org/uploadedFiles/wwwpewtrustsorg/Reports/Clean_Energy/Clean\%20 Energy\%20Race\%20Report\%202012.pdf.

2"Sizing the Clean Economy: The Clean Economy in the State of Indiana." The Brookings Institution and Battelle, July 2011. http://www.brookings.edu/ /media/Series/Clean\%20Economy/18.pdf.

3"Wind Resource Potential." EERE, 2010. http://www.windpoweringamerica.gov/windmaps/ resource_potential.asp.

4"NREL's Wind Powering America Team Helps Indiana Develop Wind Resources." NREL, October 2010. http://www.nrel.gov/docs/fy11osti/48938.pdf.

s"Annual State Personal Income and Employment" and "Gross Domestic Product by State." U.S. Bureau of Economic Analysis, 2012 http://www bea gov/iTable/iTable cfm?reqid=70\&step=1\&isuri=1

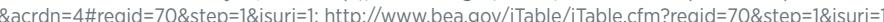
\&acrdn=1\#

6"Cause \#42693." Indiana Utility Regulatory Commission, December 2009. http://www.in.gov/iurc/ files/Cause_No._42693.pdf.

Assumes savings equal to $2 \%$ of 2010 electricity consumption.

"“Database of State Incentives for Renewables \& Efficiency," EERE, 2012. http://www.dsireusa.org/.

g"Low Cost U.S. Manufacturing of Power Electronics for Electric Drive Vehicles." Delphi Automotive Systems, May 2012. http://www1.eere.energy.gov/vehiclesandfuels/pdfs/merit review 2012/ adv_power_electronics/arravt022_ape_grant_2012_p.pdf.

"o "2011 DOE Vehicle Technologies Review: Gasoline Ultra Fuel Efficient Vehicle," Delphi Automotive Systems, May 2012. http://www1.eere.energy.gov/vehiclesandfuels/pdfs/merit_review_2012/ adv_combustion/ace064_confer_2012_o.pdf.

I"“Innovative Manufacturing Initiative." EERE, 2012. http://www5.eere.energy.gov/projects/foa/ project/innovative-manufacturing-initiative.

12“Electric Drive Component Manufacturing Facilities." Allison Transmission, May 2011. http://www1.eere.energy.gov/vehiclesandfuels/pdfs/merit_review_2011/adv_power_electronics/ arravt023 ape tuttle 2011 p.pdf.

13“"Providing Vehicles OEMs Flexible Scale to Accelerate Adoption of Electric Drive Vehicles." Remy International, May 2012. http://www1.eere.energy.gov/vehiclesandfuels/pdfs/merit review_2012/ adv_power_electronics/arravt025_ape_shives_2012_p.pdf.

14“SuperTruck - Development and Demonstration of a Fuel- Efficient Class 8 Tractor \& Trailer:" Navistar May 2012 http:/www1.eere energy_gov/vehiclesandfuels/pdfs/merit_review 2012/ veh_sys_sim/vss064_jadin_2012_o.pdf.

15“Technology and System Level Demonstration of Highly Efficient and Clean, Diesel Powered Class 8 Trucks." Cummins, May 2012. http://www1.eere.energy.gov/vehiclesandfuels/pdfs/merit_review_2012/ adv_combustion/ace057_koeberlein_2012_o.pdf.

16 “Recovery Act Announcement." EERE, January 11, 2010. http://apps1.eere.energy.gov/news/ progress_alerts.cfm/pa_id=284.
17“EERE Network News.” EERE, April 4, 2012. http://apps1.eere.energy.gov/news/archive.cfm/ pubDate $=\% 7 \mathrm{Bd} \% 20 \% 272012-04-04 \% 27 \% 7 \mathrm{D}$.

18 "Steel Manufacturer Proves its 'Mittal' by Doing More with Less Energy." DOE, November 2010. http://energy.gov/articles/steel-manufacturer-proves-its-mittal-doing-more-less-energy.

19"Recovery Act and the State Energy Program" and "EECBG Allocations for Indiana." EERE, 2010. http://www1.eere.energy.gov/wip/recovery_act_sep.html; http://wwwl.eere.energy.gov/wip/ eecbg state allocations

20"Greenhouse Gas Equivalencies Calculator." EPA, 2010. http://www.epa.gov/cleanenergy/energyresources/calculator.html.

21"Residential Energy Consumption Survey." U.S. Energy Information Administration, 2009. http://www.eia.gov/consumption/residential/.

22"Greening of the City-County Building." City of Indianapolis, 2011. http://www.youtube.com/ watch?v=ayJ5EykSisw.

23“"Indiana Energy Insights." Indiana Office of Energy Development, December 8, 2011. http://indianaenergyinsights.blogspot.com/2011/12/warrick-county-lights-it-up-with-eecbg.html.

24“Retrospective Benefit-Cost Evaluation of U.S. DOE Vehicle Combustion Engine R\&D Investments: Impacts of a Cluster of Energy Technologies." DOE, May 2010. http://www1.eere.energy.gov/analysis/pdfs/advanced_combustion_report.pdf.

25"Retrospective Benefit-Cost Evaluation of DOE Investment in Photovoltaic Energy Systems." DOE, August 2010. http://www1.eere.energy.gov/analysis/pdfs/solar_pv.pdf.

26"Retrospective Benefit-Cost Evaluation of U.S. DOE Wind Energy R\&D Program," DOE, June 2010. http://www1.eere.energy.gov/analysis/pdfs/wind_bc_report10-14-10.pdf.

${ }^{27}$ National Research Council. Energy Research at DOE: Was It Worth It? Energy Efficiency and Fossil Energy Research 1978 to 2000. Washington, DC: National Academies Press, 2001.

28“"DOE Hydrogen and Fuel Cells Program Record \#12020," DOE, September 27, 2012 http://hydrogen.energy.gov/pdfs/12020_fuel_cell_system_cost_2012.pdf. Based on projections to high-volume manufacturing.

29"Retrospective Benefit -Cost Evaluation of DOE Investment in Photovoltaic Energy Systems." DOE, August 2010. http://www1.eere.energy.gov/analysis/pdfs/solar_pv.pdf.

30“Retrospective Benefit-Cost Evaluation of U.S. DOE Wind Energy R\&D Program," DOE, June 2010. http://www1.eere.energy.gov/analysis/pdfs/wind_bc_report10-14-10.pdf.

31“"Weatherization Assistance Program.” EERE, May 2009. http://www1.eere.energy.gov/wip/pdfs/ wap_factsheet.pdf.

32“"Building Technologies Program: History and Impacts.” EERE, 2013.

http://wwwleere energygov/buildings/appliance standards/history and impact.htm.

33" “Energy Technology Solutions: Public-Private Partnerships Transforming Industry.” EERE, Decembe 2010. http://www1.eere.energy.gov/manufacturing/pdfs/itp_successes.pdf.

34"Facilitating Cost-Effective Federal Energy Management." EERE, December 2012 http://wwwl.eere.energy.gov/femp/pdfs/femp_fs.pdf.
Page 2: iStock 17393871: page 4: Dennis Schroeder. NREL 19156: page 5: Jim Tetro, U.S. Department of Energy Solar Decathlon 


\section{A Proven Track Record}

\section{Snapshot of National Outcomes from EERE Investments}

- EERE's \$931 million investment in vehicles combustion engine R\&D from 1986 to 2007 achieved a net benefit of $\$ 69$ billion (2008 dollars) in fuel savings for users of heavy-duty diesel trucks. ${ }^{24}$

- EERE's \$3.7 billion investment in solar photovoltaic R\&D from 1975 to 2008 resulted in a net economic benefit of \$15 billion (2008 dollars) due to module efficiency and reliability improvements. ${ }^{25}$

- EERE’s $\$ 1.7$ billion investment in wind energy R\&D from 1976 to 2008 resulted in a net economic benefit of \$8.7 billion (2008 dollars) due to wind turbine efficiency, energy capture, and reliability improvements. ${ }^{26}$

- A 2001 National Academy of Sciences analysis found that investments of \$1.6 billion in energy efficiency R\&D in the first two decades of DOE's existence from 1978 to 2000 realized a net economic benefit of approximately $\$ 30$ billion (1999 dollars). ${ }^{27}$

\section{Sustainable Transportation}

- EERE research has helped reduce production costs of automotive lithium-ion batteries by more than $50 \%$ since 2008 and is on track to reach its goal of enabling cost-competitive market entry of plug-in hybrid electric vehicles within the next 10 years.

- EERE's activities to achieve cost-competitiveness for biofuels have resulted in the recent achievement of reaching a modeled cellulosic ethanol production cost of $\$ 2.15$ per gallon of ethanol (or \$3.27 per gallon of gasoline equivalent).

- EERE's efforts have reduced the projected costs of automotive fuel cells (assuming high-volume manufacturing) by more than $35 \%$ since 2008 and $80 \%$ since 2002-doubling the durability of fuel cells from 950 hours of demonstrated operation in 2006 to more than 2,500 hours of operation on the road. ${ }^{28}$

\section{Renewable Electricity Generation}

- Without EERE involvement, the average solar photovoltaic (PV) module production cost per watt would have been $\$ 5.27$ in 2008, rather than \$1.92. EERE has accelerated solar industry progress by an estimated 12 years. ${ }^{29}$

- Without EERE involvement, cumulative wind power deployment through 2008 would have been less than a third of actual 2008 levels. EERE has accelerated the overall progress of the wind industry by an estimated 6 years. ${ }^{30}$

\section{Energy-Saving Homes,}

Buildings, and Manufacturing

- More than 6,200,000 homes have been weatherized with EERE funding provided to states or leveraged from other sources with EERE support since 1976 - creating an average energy savings of $\$ 350$ or more per year and avoiding \$1.6 billion in energy costs during winter 2005 alone for all households weatherized. ${ }^{31}$

- Due to EERE appliance standards implemented through 2012, a typical household today already saves about $\$ 180$ per year off its utility bills. Households can expect to save more than $\$ 300$ per year by 2030 , as they replace their existing appliances with newer models that use less energy - a cumulative savings to consumers of more than $\$ 900$ billion by 2020 , and more than $\$ 1.6$ trillion through 2030 . The cumulative energy savings of these standards phased in through 2012 will be about 70 quadrillion British thermal units (quads) of energy through 2020, and will amount to 120 quads through 2030. (The United States consumes a total of about 100 quads of energy per year.) ${ }^{32}$

- EERE and its partners in the manufacturing sector have successfully launched 220 new, energy-efficient technologies, received 78 R\&D 100 Awards, and delivered technical assistance to more than 33,000 industrial plants. ${ }^{33}$

- Since 2005, EERE has facilitated $\$ 3.1$ billion of efficiency investments in federal government facilities from performance-based contracts, which will result in energy cost savings of approximately $\$ 8.5$ billion over the life of the energy-saving measures. The savings on utility bills and operation and maintenance created through the facility upgrades will be used to pay for the project over the term of the contract, and the agencies will continue to save money and energy after the contract term has ended. ${ }^{34}$

The Office of Energy Efficiency and Renewable Energy is at the center of creating the clean energy economy today. We lead U.S. Department of Energy efforts to develop and deliver market-driven solutions for renewable electricity generation; sustainable transportation; and energy-saving homes, buildings, and manufacturing. To learn more about the activities of the Office of Energy Efficiency and Renewable Energy, visit eere.energy.gov. If you have questions or comments about the information in this document, please contact us at EE.Communications@ee.doe.gov.

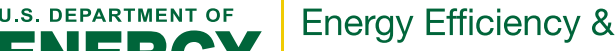 ENERGY Renewable Energy}

